\title{
Evaluation of sub daily satellite rainfall estimates through flash flood modelling in the Lower Middle Zambezi Basin
}

\author{
Thomas Matingo, Webster Gumindoga, and Hodson Makurira \\ Department of Civil Engineering, University of Zimbabwe, P.O. Box MP167, Mt Pleasant, Harare, Zimbabwe \\ Correspondence: Thomas Matingo (engineermatingo@gmail.com), Webster Gumindoga \\ (wgumindoga@gmail.com), and Hodson Makurira (hmakurira@ yahoo.com)
}

Received: 12 November 2017 - Revised: 12 January 2018 - Accepted: 15 January 2018 - Published: 29 May 2018

\begin{abstract}
Flash floods are experienced almost annually in the ungauged Mbire District of the Middle Zambezi Basin. Studies related to hydrological modelling (rainfall-runoff) and flood forecasting require major inputs such as precipitation which, due to shortage of observed data, are increasingly using indirect methods for estimating precipitation. This study therefore evaluated performance of CMORPH and TRMM satellite rainfall estimates (SREs) for $30 \mathrm{~min}, 1 \mathrm{~h}, 3 \mathrm{~h}$ and daily intensities through hydrologic and flash flood modelling in the Lower Middle Zambezi Basin for the period 2013-2016. On a daily timestep, uncorrected CMORPH and TRMM show Probability of Detection (POD) of 61 and $59 \%$, respectively, when compared to rain gauge observations. The best performance using Correlation Coefficient (CC) was 70 and $60 \%$ on daily timesteps for CMORPH and TRMM, respectively. The best RMSE for CMORPH was $0.81 \%$ for 30 min timestep and for TRMM was $2,11 \%$ on $3 \mathrm{~h}$ timestep. For the year 2014 to 2015, the HEC-HMS (Hydrological Engineering Centre-Hydrological Modelling System) daily model calibration Nash Sutcliffe efficiency (NSE) for Musengezi sub catchment was $59 \%$ whilst for Angwa it was 55\%. Angwa sub-catchment daily NSE results for the period 2015-2016 was $61 \%$. HEC-RAS flash flood modeling at 100, 50 and 25 year return periods for Angwa sub catchment, inundated 811 and 867 ha for TRMM rainfall simulated discharge at $3 \mathrm{~h}$ and daily timesteps, respectively. For CMORPH generated rainfall, the inundation was $818,876,890$ and $891 \mathrm{ha}$ at daily, $3 \mathrm{~h}, 1 \mathrm{~h}$ and 30 min timesteps. The $30 \mathrm{~min}$ time step for CMORPH effectively captures flash floods with the measure of agreement between simulated flood extent and ground control points of $69 \%$. For TRMM, the $3 \mathrm{~h}$ timestep effectively captures flash floods with coefficient of $67 \%$. The study therefore concludes that satellite products are most effective in capturing localized hydrological processes such as flash floods for sub-daily rainfall, because of improved spatial and temporal resolution.
\end{abstract}

\section{Introduction}

Accurate measurement of precipitation is key for dependable hydrologic predictions (Guo et al., 2015). Rain gauges are traditionally used to measure precipitation and have a drawback of reduced spatial coverage (Blacutt et al., 2015) thus rendering hydrological predictions inaccurate (Ning et al., 2016). it is impossible to place rain gauge stations at all places of interest. Therefore, satellite rainfall helps to augment the sparse rain gauges coverage (Maidment Ross et al., unpublished data, 2017). Nowadays satellite rainfall products such as Climate Prediction Centre Morphing technique (CMORPH), Tropical Rainfall Measuring Mission (TRMM) and Precipitation Estimation from Remotely Sensed Infor- mation using Artificial Neural Networks (PERSIANN) are produced at a spatial resolution of $8 \mathrm{~km}$ and temporal resolution of $3 \mathrm{~h}$. Due to their indirect nature of measurements, satellite rainfall estimates (SREs) contain errors which can be divided into two groups; (i) systematic (bias) and (ii) random errors (Liu, 2015). As such, bias correction is needed before SREs are used with confidence in water resources applications. Previous studies in the Middle Zambezi Basin such as by Samuel Mwanangombe (unpublished data, 2015) only concentrated on highlighting the spatial aspects in SREs but ignored the temporal aspect in the hydrological outputs. Flash floods occur within a short period of time such that daily time scale used in previous studies may not be adequate 


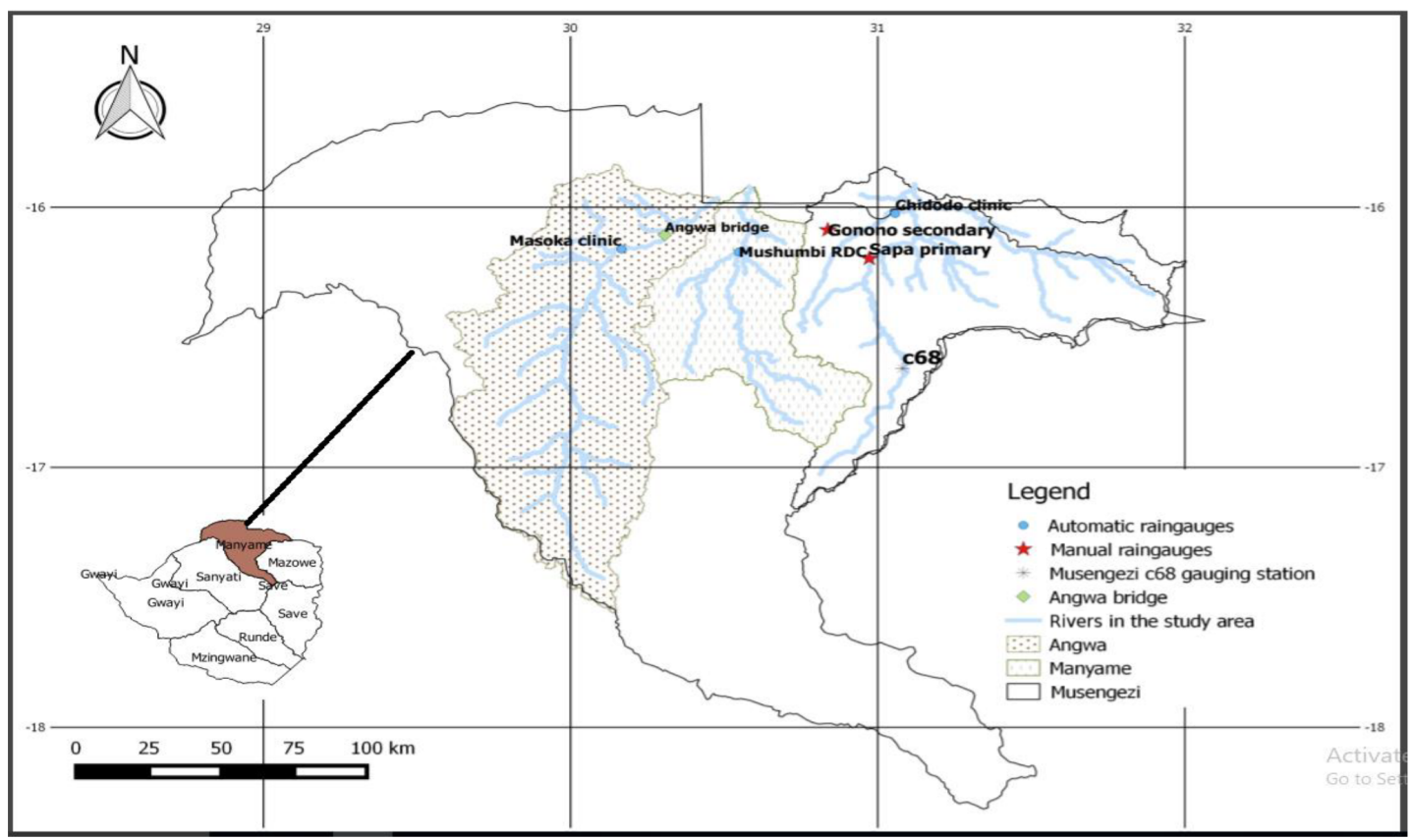

Figure 1. The Mbire District in Lower Guruve showing manual and automatic rain gauge stations.

to capture flash floods (Saber and Yilmaz, 2016). Floods are mostly localized. Besides the need for high spatial resolution to focus on floods, there is also need for temporal resolution such as sub daily time scales to capture the actual flood processes (Chen et al., 2016). By their improved spatial coverage and ability to provide rainfall estimates at recurrent time steps. SREs are suitable for basin-wide applications such capturing flash floods in cases where rain gauge measurements are not available. This is a welcome development in study sites such as Mbire District where there is limited spatial and temporal cover of automated recording rain gauges. The objective of this study was therefore to assess the performance of SREs at finer temporal resolutions and then applying the generated data in rainfall-runoff and flash flood modelling in the middle Zambezi Basin.

\section{Study Area}

The study area covers 3 sub-catchments of Manyame cutting through the Mbire District of Zimbabwe, namely, Angwa, Lower Manyame and Musengezi. Mbire District lies between 30.60 and $31.20^{\circ} \mathrm{E}$ and 15.60 and $16.40^{\circ} \mathrm{S}$. The estimated area of Mbire District is approximately $4700 \mathrm{~km}^{2}$ and is characterized mainly by the floodplains of the Zambezi River Basin. The altitude is approximately $400 \mathrm{~m}$ above sea level and being drained by the Angwa, Manyame, Musengezi and Kadzi rivers (Fig. 1). Mbire District receives low rainfall of below $600 \mathrm{~mm}$ and lies in agro ecological region IV of Zimbabwe (Bola et al., 2014). The district records high temperatures (sometimes exceeding $40^{\circ} \mathrm{C}$ ) with mean annual tem- perature of $25^{\circ} \mathrm{C}$, Mbire District lies on sedimentary geological foundations of lime and sandstone formations. Varied soils rich in sodium exist though lacking in organic matter. Mbire District experiences frequent localised flooding (CPU, unpublished data, 2015). Backflow from the downstream Cahora Bassa Dam and rainfall events from the large upstream catchment are the two main factors that contribute to flooding (Bola et al., 2014). Angwa, Manyame, Musengezi sub-basins have been selected since these are the major rivers in the area and greatly contribute to flooding (Bola et al., 2014).

\section{Methodology}

\subsection{Gauge based rainfall data}

Rainfall for November 2015 to December 2016 with temporal resolution of $30 \mathrm{~min}$ was acquired from three automatic weather stations located at Chidodo, Masoka and Mushumbi. The $30 \mathrm{~min}$ data was aggregated to $1 \mathrm{~h}, 3 \mathrm{~h}$ and daily timestep. Before 2015, there was no sub-daily rainfall data available from rain gauges. The automatic rain gauges were installed in October 2015 and these provide sub daily temporal resolution rainfall data. One year of observations would not lead to convincing conclusions hence the need to lengthen the period of analysis using the "Hydrognomon" software (Kozanis et al., 2005). The daily time series for 2013 to October 2015 was disaggregated to lengthen the comparison time series. 


\subsection{Satellite rainfall download and processing}

TRMM and CMORPH rainfall data were downloaded using ILWIS 3.7.2 software through the GeoNETCAST ISOD toolbox. The point to pixel method was used for comparison of gauge rainfall and satellite rainfall. A maplist was created and crossed to the rain gauge stations point map to extract satellite rainfall values.

The rain gauge stations point map was used to extract satellite rainfall values from the grid CMORPH and TRMM rainfall.

\subsection{Performance evaluation of satellite products through standard statistics}

CMORPH and TRMM Satellite rainfall for 2013 to 2015 were compared with rain gauge data by means of detection statistics and standard statistical analysis. The detection statistics and statistical analysis used are POD, RMSE, CC and Rbias using the following equations:

$$
\begin{aligned}
& \mathrm{POD}=H / H+M \\
& \mathrm{FAR}=F / H+F \\
& \mathrm{FBIAS}=F+H / H+M \\
& \mathrm{CSI}=H / H+M+F \\
& \mathrm{Rbias}=\frac{\varepsilon\left(P_{\mathrm{s}}-P_{\mathrm{r}}\right)}{\varepsilon P_{\mathrm{r}}} \\
& \mathrm{RMSE}=\sqrt{ } \frac{\left(P_{\mathrm{s}}-P_{\mathrm{r}}\right)^{2}}{N} \\
& \mathrm{CC}=\frac{\varepsilon\left(P_{\mathrm{r}}-P_{\mathrm{mr}}\right)\left(P_{\mathrm{S}}-P_{\mathrm{ms}}\right)}{\sqrt{ }\left(\varepsilon\left(P_{\mathrm{r}}-P_{\mathrm{mr}}\right)^{2}\right) \sqrt{ } \varepsilon\left(P_{\mathrm{s}}-P_{\mathrm{ms}}\right)^{2}}
\end{aligned}
$$

Where $H=$ hit bias, $M=$ miss bias, $F=$ false bias, $\mathrm{FAR}=$ false alarm ratio, $\mathrm{POD}=$ probability of detection, $\mathrm{CSI}=$ critical success index, FBIAS $=$ frequency bias, $P_{\mathrm{s}}=$ satellite rainfall estimates $\left(\mathrm{mm} \mathrm{day}^{-1}\right), P_{\mathrm{ms}}=$ mean values of $\operatorname{SRE}\left(\mathrm{mm} \mathrm{day}^{-1}\right), \quad P_{\mathrm{r}}=$ rain gauge rainfall $\left(\mathrm{mm} \mathrm{day}^{-1}\right), \quad P_{\mathrm{mr}}=$ mean values of rain gauge rainfall $\left(\mathrm{mm} \mathrm{day}^{-1}\right), N=$ sample size in days.

\subsection{Bias correction of satellite rainfall}

For correcting the satellite rainfall, a correction factor $\left(\mathrm{BF}_{\mathrm{stb}}\right)$ was calculated using Eq. (8). The multiplicative bias factor corrects for the spatial and temporal aspects of the error in satellite rainfall (Bhatti et al., 2016; Habib et al., 2014; Gumindoga et al., 2016a).

$$
\mathrm{BF}_{\mathrm{stb}}=\frac{\sum_{t=d}^{t=d-l} S(i, t)}{\sum_{t=d}^{t=d-l} G(i, t)}
$$

Where $G$ and $S=$ daily gauge and satellite rainfall estimates, respectively $(\mathrm{mm}), i=$ gauge location, $t=$ julian day number (day), $l=$ length of a time window for bias calculation (days), $n=$ the total number of gauges within the entire domain of the study, $T=$ full duration of the study period.

\subsection{HEC HMS model setup}

\subsubsection{Land surface parameterization}

A Shuttle Radar Topography Mission (SRTM) Digital Elevation Model (DEM) at $90 \mathrm{~m}$ resolution was obtained from the following website: http://srtm.csi.cgiar.org/. The DEM was imported in ILWIS for DEM hydro processing. Catchment merging was conducted to derive the 3 sub-catchments. The catchment maps were exported from ILWIS as ESRI shapefiles together with the river shapefiles after which a basin model was created in HEC-HMS (Abushandi and Merkel, 2013; Gumindoga et al., 2016b; Narayan and Gautam, 2015). The deficit and constant loss method and the SCS unit Hydrograph Transformation methods were used for the component (Bhuiyan et al., 2017). The Muskingum method was used for reach routing.

\subsubsection{Model calibration, validation and model efficiency assessment}

The HEC HMS 3.5 model was manually calibrated for daily timestep simulation with Angwa and Musengezi catchments flow dataset for the period 1 October 2014 to 30 September 2015. The calibrated parameters were time lag and percentage impervious (Gumindoga et al., 2016b). Simulated runoff was compared with the measured runoff for Angwa and Musengezi catchments. The performance indicators used to assess the model differences between observed and simulated were the Nash-Sutcliffe efficiency (NSE) and Relative Volume Error (RVE). For validation of the model, one hydrological year; October 2015 to September 2016 was used. All the parameters obtained during model calibration were maintained but the hydro-meteorological series were changed.

\subsubsection{Runoff simulation for different timesteps}

The loss and transformation parameters for the calibrated daily timestep were transferred to $30 \mathrm{~min}, 1 \mathrm{~h}$ and $3 \mathrm{~h}$ timesteps. To check the performance for these timesteps; total volume, time of peak and peak discharge were compared to the standard daily time step gauge.

\subsection{HECRAS flash flood modelling}

The Angwa sub-catchment $30 \mathrm{~m}$ SRTM DEM was used to create a TIN in HEC-GeoRAS. Geometric data relating to centreline, cross section lines, river banks and flow path from ArcView was exported to HECRAS to generate water surface profiles and flood way boundaries. Discharge for different timesteps from HEC-HMS was used to evaluate the performance. For each discharge, standard deviation and the mean were calculated using the Gumbel method for 100, 50 and 25 year flood events. The measure of agreement was calculated using Cohen Kappa in SPSS package for the validation of the flood simulation. 


\section{Results and Discussion}

\subsection{Evaluation of satellite rainfall product}

Figure 2 shows standard statistics error at different timesteps. The Correlation Coefficient (CC) for TRMM and CMORPH decreases with decreasing timestep. Shen et al. (2010) evaluated performance of TRMM and CMORPH in China at different timescales such as daily, 12, 6, 3h and found out that $\mathrm{CC}$ increases with increase in timestep which is similar to the finding of this study. POD for all satellite products decreases with decrease in timestep such as from daily to $3 \mathrm{~h}$. CMORPH decreases from 0.61 to 0.5 whilst TRMM from 0.59 to 0.31 . FBI was smaller than one for TRMM satellite product meaning that it have a tendency of underestimating rainfall whilst CMORPH; FBI was 2.02 which shows a tendency of overestimation which is in agreement with results by Yang and Luo (2014) who found FBI of 4.6 and also a study in the Zambezi Basin by Cohen Liechti et al. (2012) who found FBI of 2.9 at daily timesteps.

\subsection{Bias correction results}

After bias correction, the RMSE reduced by $12 \%$ and Rbias by $33 \%$ on daily time step. This finding of reduction of RMSE after bias correction application tallies with the findings by Gumindoga et al. (2016a), who reduced RMSE by $11 \%$ with similar bias correction on a daily timestep in the Zambezi River Basin. The effect of reducing RMSE after application of bias correction was also found by Bhatti et al. (2016) who decreased RMSE by $7 \%$ on daily timestep in the Gilgel Abbey catchment.

\subsection{HEC-HMS calibration and validation with rain gauge rainfall}

The calibration results for Angwa and Musengezi upstream for the period of October 2014 to September 2015 are shown in Fig. 3. The Nash Sutcliffe (NSE) was $55 \%$ and Relative Volume Error (RVE) was $-9.4 \%$ which is within acceptable range of -10 and $10 \%$ (Janssen and Heuberger, 1995). The negative sign shows that the model underestimated runoff. This can be attributed to the assumption made that ignored the contribution of base flow in the calibration of the model. For Musengezi upstream, the NSE was $58 \%$ which shows that the model reproduced the observed patterns fairly well. The relative volume error was $-7.7 \%$. The RVE differs from Gumindoga et al. (2016b) in the same basin which was $-1.54 \%$.

Model validation for the period of October 2015 to September 2016 was carried out successfully for Angwa River with a NSE of $61 \%$ which is within the accepted range. However, the RVE obtained of $42 \%$ is outside the acceptable range. Figure 4 shows the hydrograph for validation.

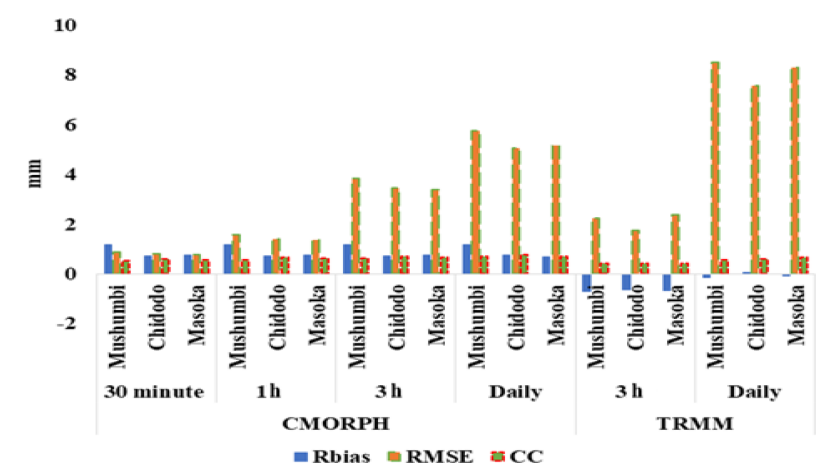

Figure 2. Standard statistic error for both SREs at different timesteps.
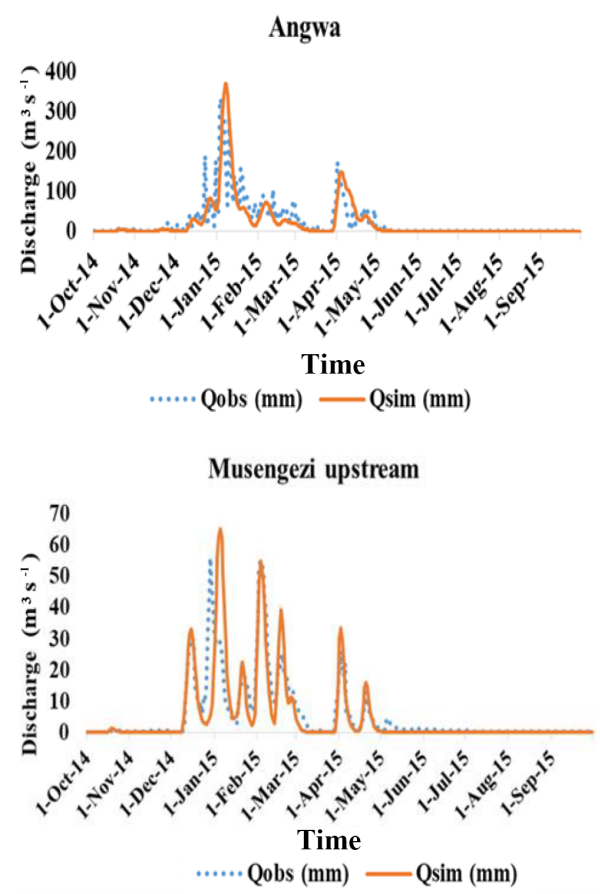

Figure 3. Calibration results for Angwa and Musengezi rivers upstream based on daily timestep.

\subsection{HEC-HMS model simulation with SREs at different timesteps}

Table 1 was acquired as an output from the HEC-HMS model and it shows that peak discharge increases with decrease in timestep. This finding is consistent with results from Bruce Mcenroe (unpublished data, 2010) which showed that simulated runoff increases with a decrease in timesteps considered. This shows that coarser timesteps do not necessarily imply higher peaks. A finer timestep might record some of the maximum rainfall amounts that might actually be missed by a coarser timestep. 
Table 1. Characteristics of catchments acquired from the model basing on different timestep for both satellite rainfall products for October 2014 to September 2015.

\begin{tabular}{|c|c|c|c|c|}
\hline Catchments & $\begin{array}{r}\text { Drainage area } \\
\qquad\left(\mathrm{km}^{2}\right)\end{array}$ & $\begin{array}{r}\text { Peak Discharge } \\
\qquad\left(\mathrm{m}^{3} \mathrm{~s}^{-1}\right)\end{array}$ & Time of peak & $\begin{array}{r}\text { Volume } \\
\left(1000 \mathrm{~m}^{3}\right)\end{array}$ \\
\hline \multicolumn{5}{|c|}{ Rain gauge rainfall daily data } \\
\hline Angwa & 9502 & 259.1 & 7 January 2015 & 561686.4 \\
\hline Musengezi upstream & 951 & 38.1 & 4 January 2015 & 102415.9 \\
\hline \multicolumn{5}{|c|}{$\mathrm{CMORPH}$ satellite rainfall $3 \mathrm{~h}$ data } \\
\hline Angwa & 9502 & 3135.6 & 5 January 2015 & 2898026.9 \\
\hline Musengezi upstream & 951 & 250.6 & 2 February 2015 & 365226.7 \\
\hline \multicolumn{5}{|c|}{ TRMM satellite rainfall $3 \mathrm{~h}$ data } \\
\hline Angwa & 9502 & 106 & 12 January 2015 & 285114.6 \\
\hline Musengezi upstream & 951 & 51.4 & 5 January 2015 & 45950.3 \\
\hline \multicolumn{5}{|c|}{ CMORPH satellite rainfall $1 \mathrm{~h}$ data } \\
\hline Angwa & 9502 & 3581.6 & 5 January 2015 & 3185872.3 \\
\hline Musengezi-upstream & 951 & 276.8 & 2 February 2015 & 393687.5 \\
\hline \multicolumn{5}{|c|}{ CMORPH satellite rainfall $30 \mathrm{~min}$ data } \\
\hline Angwa & 9502 & 3689.8 & 5 January 2015 & 3458287.1 \\
\hline Musengezi-upstream & 951 & 279.6 & 02 February 2015 & 420255.6 \\
\hline
\end{tabular}

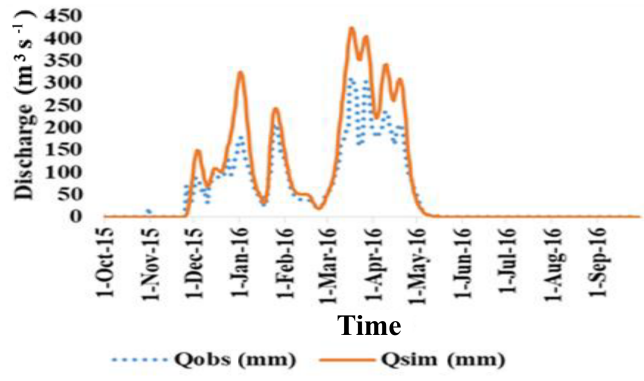

Figure 4. Validation hydrograph for Angwa.

\subsection{Application of bias corrected SREs into flash flood modelling}

Figure 5 shows the area of inundation. For both satellites, flood extent for daily timestep was smaller than $3 \mathrm{~h}$ timestep. This confirms that flash floods, by their name, occur rapidly within a short period of time and immediately disappear such that daily timestep captures a lesser extent of flooded area. At a finer timestep such as $30 \mathrm{~min}$ and $1 \mathrm{~h}, \mathrm{CMORPH}$ simulates the flash floods better than TRMM. The area of inundation by TRMM generated discharge is less than that of CMORPH generated discharge.

\subsection{Validation of HECRAS flood simulation}

The Cohen Kappa statistic shows that the ground control points were in agreement with the simulated flood plain by

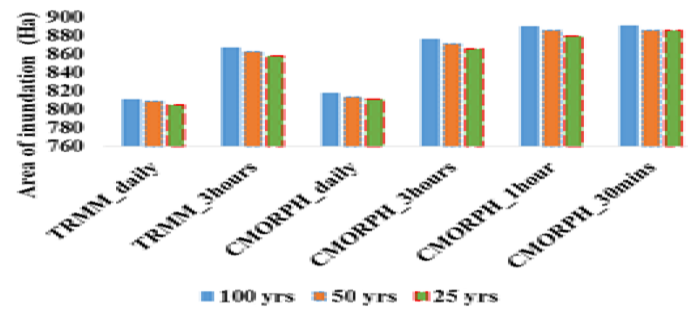

Figure 5. Comparison of area of inundation for two satellites on different time step.

HECRAS. The coefficients were as follows: $(P<0.05)$ of 69 , 67, 66.7, 54, 67 and $62 \%$ for CMORPH $30 \mathrm{~min}, 1 \mathrm{~h}, 3 \mathrm{~h}$, daily, TRMM $3 \mathrm{~h}$ and TRMM daily satellite precipitation respectively. Finer timesteps capture all floods since they are measured instantaneously whereas coarser timesteps present a mean over a period in question.

Figure 6 shows the best flood extent polygon at $30 \mathrm{~min}$ timestep and 100 year return period overlaid on google map. It can be seen that cultivating area is mostly at great risk when floods occur.

\section{Conclusions}

Both CMORPH and TRMM applications exhibit bias factors which were too large and, hence, warranted bias correction before application in hydrological and hydraulic modelling. 


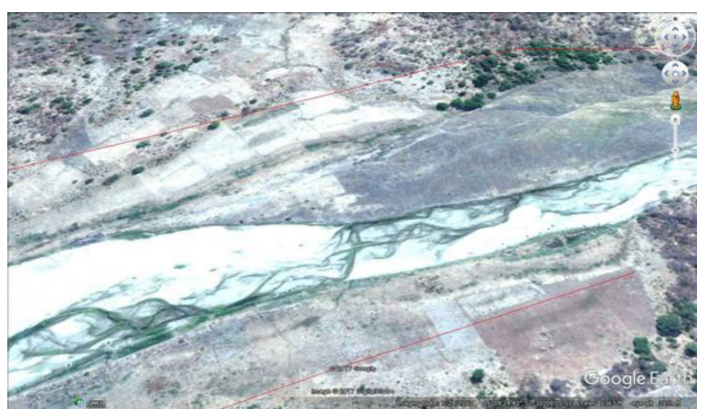

Figure 6. Flood extent polygon for 100 year return period at $30 \mathrm{~min}$ timestep at Masoka.

CMORPH also performed better than TRMM in terms of NSE and RVE when applied to the HEC-HMS model.

Since the flooded area was at finer timescales than for the aggregated daily timescales, it can also be concluded that floods occur rapidly and the chances of capturing them are higher when finer resolution of measurement are applied.

Data availability. The data is accessible on request from the authors.

Competing interests. The authors declare that they have no conflict of interest.

Special issue statement. This article is part of the special issue "Understanding spatio-temporal variability of water resources and the implications for IWRM in semi-arid eastern and southern Africa". It is a result of the IAHS Scientific Assembly 2017, Port Elizabeth, South Africa, 10-14 July 2017.

Acknowledgements. WaterNet is highly acknowledged for supporting this research. The authors greatly appreciate the Department of Civil Engineering for providing the platform to carry out the research and helping to shape its successful conclusion.

Edited by: Evison Kapangaziwiri

Reviewed by: Amidu Owolabi Ayeni and one anonymous referee

\section{References}

Abushandi, E. and Merkel, B.: Modelling Rainfall Runoff Relations Using HEC-HMS and IHACRES for a Single Rain Event in an Arid Region of Jordan, Water Resour. Manag., 27, 2391-2409, https://doi.org/10.1007/s11269-013-0293-4, 2013.

Bhatti, H. A., Rientjes, T., Haile, A. T., Habib, E., and Verhoef, W.: Evaluation of Bias Correction Method for, Sensors, 16, 1072510748, https://doi.org/10.3390/s16060884, 2016.

Bhuiyan, H. A. K. M., Mcnairn, H., Powers, J., and Merzouki, A.: Application of HEC-HMS in a Cold Region Watershed and
Use of RADARSAT-2 Soil Moisture in Initializing the Model, Hydrology, 4, 1-19, https://doi.org/10.3390/hydrology4010009, 2017.

Blacutt, L. A., Herdies, D. L., Gustavo, L., Gonçalves, G. De, Vila, D. A., and Andrade, M.: Precipitation comparison for the CFSR, MERRA, TRMM3B42 and Combined Scheme datasets in Bolivia, Atmos. Res., 163, 117-131, https://doi.org/10.1016/j.atmosres.2015.02.002, 2015.

Bola, G., Mabiza, C., Goldin, J., Kujinga, K., Nhapi, I., Makurira, H., and Mashauri, D.: Coping with droughts and floods: A Case study of Kanyemba, Mbire District, Zimbabwe, Phys. Chem. Earth, 67-69, 180-186, https://doi.org/10.1016/j.pce.2013.09.019, 2014.

Chen, X., Zhang, L., Gippel, C. J., Shan, L., Chen, S., and Yang, W.: Uncertainty of Flood Forecasting Based on Radar Rainfall Data Assimilation, Hindawi Publ. Corp., Adam House, London, UK, 2016.

Cohen Liechti, T., Matos, J. P., Boillat, J.-L., and Schleiss, A. J.: Comparison and evaluation of satellite derived precipitation products for hydrological modeling of the Zambezi River Basin, Hydrol. Earth Syst. Sci., 16, 489-500, https://doi.org/10.5194/hess-16-489-2012, 2012.

Gumindoga, W., Rientjes, T. H. M., Haile, A. T., Makurira, H., and Reggiani, P.: Bias correction schemes for CMORPH satellite rainfall estimates in the Zambezi River Basin, Hydrol. Earth Syst. Sci. Discuss., https://doi.org/10.5194/hess-2016-33, 2016a.

Gumindoga, W., Rwasoka, D. T., Nhapi, I., and Dube, T.: Ungauged runoff simulation in Upper Manyame Catchment, Zimbabwe: Application of the HEC-HMS model, Phys. Chem. Earth, 5, 112, https://doi.org/10.1016/j.pce.2016.05.002, 2016 b.

Guo, H., Chen, S., Bao, A., Hu, J., and Yang, B.: Comprehensive Evaluation of High-Resolution Satellite-Based Precipitation Products over China, Atmosphere (Basel), 7, 1-9, https://doi.org/10.3390/atmos7010006, 2015.

Habib, E., Haile, A. T., Sazib, N., Zhang, Y., and Rientjes, T.: Effect of Bias Correction of Satellite-Rainfall Estimates on Runoff Simulations at the Source of the Upper Blue Nile, Remote Sens., 6688-6708, https://doi.org/10.3390/rs6076688, 2014.

Janssen, P. H. M. and Heuberger, P. S. C.: Calibration of process-oriented models, Ecol. Model., 83, 55-66, https://doi.org/10.1016/0304-3800(95)00084-9, 1995.

Kozanis, S., Christofides, A., Mamassis, N., and Efstratiadis, A. K.: Hydrognomon - A hydrological data management and processing software tool, Eur. Geosci. Union, 7, 04644, https://doi.org/10.13140/RG.2.2.34222.10561, 2005.

Liu, Z.: Evaluation of Precipitation Climatology Derived from TRMM Multi-Satellite Precipitation Analysis (TMPA) Monthly Product over Land with Two Gauge-Based Products, Climate, 3, 964-982, https://doi.org/10.3390/cli3040964, 2015.

Narayan, E. and Gautam, P.: Hydrological Modeling with HECHMS in Different Channel Sections in Case of Gandaki River Basin, Global Journals Inc, Wakefield, USA, 2015.

Ning, S., Wang, J., Jin, J., and Ishidaira, H.: Assessment of the Latest GPM-Era High-Resolution Satellite Precipitation Products by Comparison with Observation Gauge Data over the Chinese Mainland, Water, 41-42, https://doi.org/10.3390/w8110481, 2016.

Saber, M. and Yilmaz, K.: Bias Correction of Satellite-Based Rainfall Estimates for Modeling Flash Floods in Semi-Arid regions: 
Application to Karpuz River, Turkey, Nat. Hazards Earth Syst. Sci. Discuss., https://doi.org/10.5194/nhess-2016-339, 2016.

Shen, Y., Xiong, A., Wang, Y., and Xie, P.: Performance of high-resolution satellite precipitation products over China, J. Geophys. Res., 115, D02114, https://doi.org/10.1029/2009JD012097, 2010.
Yang, Y. and Luo, Y.: Evaluating the performance of remote sensing precipitation products CMORPH, PERSIANN, and TMPA, in the arid region of northwest China, Theor. Appl. Clim., 118, 429-445, https://doi.org/10.1007/s00704-013-1072-0, 2014. 